\title{
Comparative Analysis on Soil Basic Properties Between Southern and Northern Slopes in Funiu Mountain, China
}

\author{
Chengyuan Hao, Hebing Zhang ${ }^{*}$ and Jian Zhou
}

\author{
College of Surveying \& Land Information Engineering, Henan Polytechnic University, Jiaozuo 454003, P.R. China
}

\begin{abstract}
The spatial variation of soil physical and chemical properties in Funiu Mountain was studied to provide references for identifying soil spatial variation mechanism in bordering land of China warm temperate zone and northern subtropical region. Using vertical gradient sampling and traditional statistics method, the soil samples at the altitude from $1640 \mathrm{~m}$ to $1870 \mathrm{~m}$ were collected to compare physical and chemical properties between south and north slopes of the Funiu Mountain. The results showed that soil $\mathrm{pH}$, soil organic matter and soil total nitrogen were remarkably correlated with altitude change, but soil electrical conductivity, soil available nitrogen, available phosphors, available potassium, and total potassium were not related to altitude. With the increase of altitude, soil $\mathrm{pH}$ and total nitrogen increased, but soil organic matter decreased. Compared with the soil properties of northern slope in Funiu Mountain, soil acidity, electrical conductivity, and available nitrogen were higher in southern slope. Especially, the soil available nitrogen was much higher than the mean value observed in northern slope samples. The contents of soil organic matter, available phosphorus, available potassium, total nitrogen, and total potassium showed no striking difference on between southern and northern slopes. In conclusion, both altitude and slope direction significantly influenced spatial variation of soil properties in Funiu Mountain. It added to the boundary effect of Qinling Mountains, and revealled the interaction mechanism of the environmental elements such as land-climate-soil-ecosystem in Funiu Mountain.
\end{abstract}

Keywords: Altitude, comparison, soil properties, spatial variation, Funiu Moutain.

\section{INTRODUCTION}

Soil properties are the key ecological factors to control plant growth or fruit bearing. The research on the heterogeneity of soil basic properties at different spatial scales is beneficial to comprehend its formations and development processes. More importantly, it has major significance to understand relevant relationships between soil, biology, climate, topography, and vegetation, and some ecological processes, such as land use change, soil degeneration, and et al. [1].

As the eastward extension of Qinling Mountains, Funiu Mountain has the representative vertical distribution of physical geography in transitional region between the warm temperate zone and north subtropical zone in China [2]. So this research on spatial variation of its soil basic properties has the vital significance to explore spatial differentiation mechanism of mountainous soil and guide its land use in this transition region. The existed similar researches almost focused on the small scale because both collection and determination of soil samples need to consume too much time, labour and money [3]. And existed landscape scale researches mainly concentrated on some specific land use patterns, such as wetland, forestland, grassland, farmland. Their results largely showed that soil physicochemical properties had strong spatial physicochemical properties had strong spatial heterogeneity in large or small scale [4-7]. In China, Xiang et al. had considered that there was higher active organic carbon content in higher altitude regions of west Sichuan of China than one in lower altitude regions [8]. Zhang et al. had thought that elevation in Huoditang of Qinling Mountains had a significant correlation with $\mathrm{Ph}$, organic matter, total nitrogen, and available phosphorus [9]. Wang and Che had believed that soil organic matter content declined gradually with depth, and rose gradually with elevation [10]. And soil bulk density had obvious increasing trend on the profile level while decreasing trend on the elevation gradient. With regard to comparison between southern and northern slopes in Funiu Mountain, the existed researches almost focused on climate and vegetation [11, 12], even resources exploitation and utilization of plants or animals or tourism [13]. But till now, there is little research on soil properties. By the traditional statistical method, this research does it so as to provide the theoretical basis of mountainous environment spatial variation mechanism in borderland between warm temperate zone and north subtropical zone in China.

\section{MATERIALS AND METHODOLOGY}

\subsection{Study Area}

Funiu Mountain lies in between $110^{\circ} 30^{\prime}-113^{\circ} 05^{\prime} \mathrm{E}$ and $33^{\circ} 10^{\prime}-34^{\circ} 10^{\prime} \mathrm{N}$, with a total area of $10000 \mathrm{~km} 2$, and with relative highness difference from $1000 \mathrm{~m}$ to $1700 \mathrm{~m}$ in landform. It runs NWW to SEE stretching about 300 kilo- 


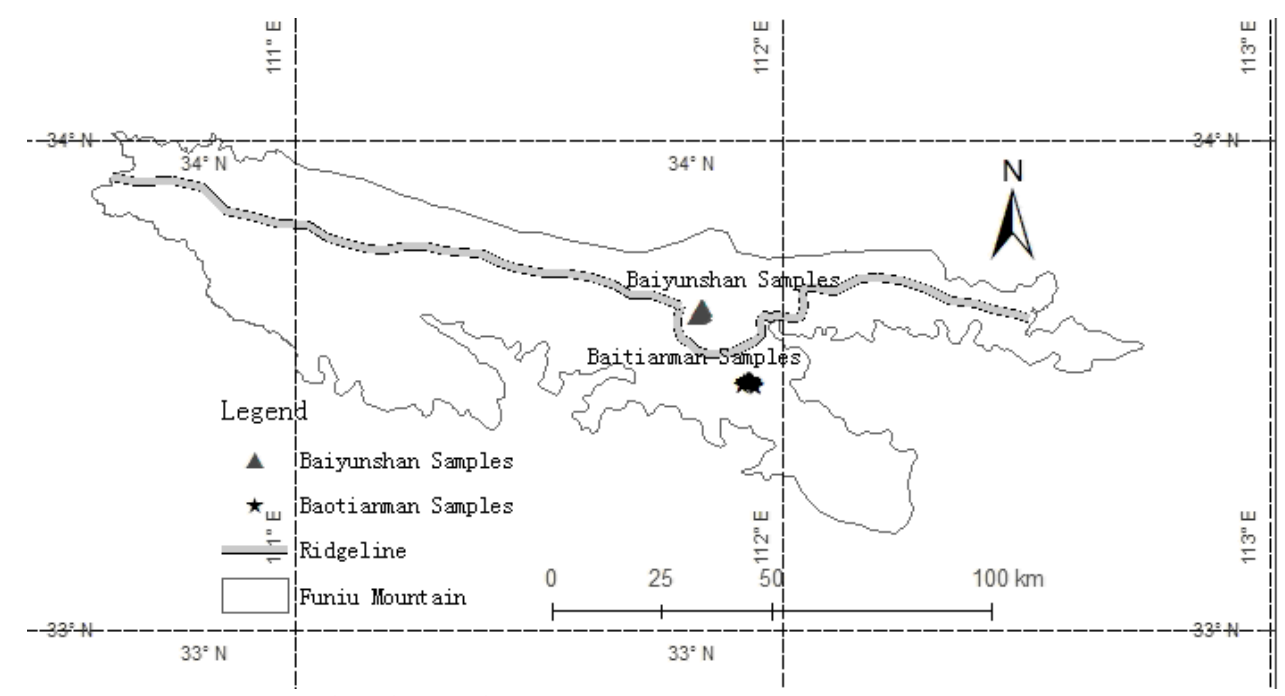

Fig. (1). Locations of Funiu Mountain and soil samplings.

meters from east to west and approximately 40-70 kilometers from south to north (Fig. (1)). Its striking characteristic is transition trait of climate and landform in south-north direction [14]. So all sampling plots of this research are located on both southern and northern slopes so as to comparative study. On southern slope, there is a national nature reserve named Baotianman, which was covered by the "Man and Biosphere Program" by UNESCO since 2001. It is the best-preserved natural comprehensive gene pool in the central region of China and one of the diversity regions in the world [15]. On northern slope, there is another national nature reserve named Funiushan, which is the water source of the Huaihe River and the drainage watershed of three river systems of the Yangtze River, the Yellow River and the Huaihe River [16], all famous for their huge runoff banks and vast watershed acreages.

\subsection{Samples Collection}

Soil samples collection were taken on from 1 to 9 of June in 2011. According to a rule named vertical gradient sampling method, setting up a plot with each $50 \mathrm{~m}$ up in this study, there are sixteen plots at the altitude from 1640 $\mathrm{m}$ to $1870 \mathrm{~m}$, nine on southern slope and seven on northern slope. At each plot, a soil profile was dug until the bedrock was reached and the main topographic variables (altitude, aspect and slope) were recorded. Surface Depth (between the top and bottom parts of the horizon) ranged between 11 and $18 \mathrm{~cm}$ for surface horizons and between 22 and $51 \mathrm{~cm}$ for subsurface horizons. The samples were homogenized and a subsample for each core was taken for laboratory analyses.

\subsection{Samples Processing and Laboratory Test}

All samplings were air-dried at room temperature for $48 \mathrm{~h}$ and passed through a $2 \mathrm{~mm}$ sieve. Identifiable root material and stones were removed during sieving, using paper bags sealed for equipment analysis. Indoor physical and chemical analysis of soil samples was performed. Soil $\mathrm{Ph}$ was measured using a 1:2 soil: water ratio after equilibration for $30 \mathrm{~min}$ [17], and electrical conductivity radiometer for soil electrical conductivity and Tyuin's method for determination of soil organic matter [18]. Available nitrogen, phosphorus and potassium were determined following extraction in $2 \mathrm{M} \mathrm{KCI}$, and extracted using acidified NH4OAc-EDTA [19], and measured using ammonium acetate method, respectively. Total nitrogen were determined a dry combustion method. Since we know the value of available potassium, and non-exchangeable potassium was analyzed with the boiling nitric acid method, total potassium can be calculated by available potassium and nonexchangeable potassium. Total phosphorus is not thought as a general supply index in this research, since its conversion is rather slow in mountainous region.

\subsection{Data Analysis}

In this article, spatial variation of soil data was analyzed with geo-statistical technique. In the first place, soil basic properties were analyzed on southern slope or northern one. And then, parameters (minimum, maximum, mean, standard deviation, and coefficient of variation) for descriptive statistics were calculated, and compared in term-by-term between southern and northern slopes.

\section{RESULTS}

\subsection{Soil basic Properties on Southern Slope}

From Table 1 of soil chemical properties of southern slope, the variation coefficients of soil $\mathrm{pH}$, organic matter and total potassium are small while ones of other indices are big, including soil conductivity, available nitrogen, available phosphorus, available potassium, total nitrogen, if being bounded by $15 \%$. Total nitrogen, especially, was correlated positively with altitude while organic matter was correlated negatively with altitude. We may clearly understand it from Fig. (2) of results through single-variable analysis of statistical package for the social sciences (shorted for SPSS). And no significant correlation was found between the other soil indices and altitude.

From Table 2 of soil chemical properties of northern slope, we knew that the variation coefficients of soil $\mathrm{Ph}$, organic matter, available nitrogen and total potassium were less than 15 percent while ones of other indices were more than 15 percent. Soil $\mathrm{pH}$ and total nitrogen were signifi- 
Table 1. Soil basic properties of southern slope in Funiu Mountain.

\begin{tabular}{|c|c|c|c|c|c|c|c|c|c|}
\hline No. & $\begin{array}{l}\text { Altitude } \\
\text { (m) }\end{array}$ & $\mathbf{p H}$ & $\begin{array}{c}\text { Electrical con- } \\
\text { ductivity } \\
(\mathrm{Ms} / \mathrm{cm})\end{array}$ & $\begin{array}{l}\text { Organic } \\
\text { matter } \\
(\mathrm{g} / \mathrm{kg})\end{array}$ & $\begin{array}{c}\text { Available ni- } \\
\text { trogen }(\mathrm{mg} / \mathrm{kg})\end{array}$ & $\begin{array}{l}\text { Available phos- } \\
\text { phorus (mg/kg) }\end{array}$ & $\begin{array}{c}\text { Available po- } \\
\text { tassium (mg/kg) }\end{array}$ & $\begin{array}{c}\text { Total } \\
\text { nitrogen } \\
(\%)\end{array}$ & $\begin{array}{c}\text { Total } \\
\text { potassium } \\
(\%)\end{array}$ \\
\hline $\mathrm{S} 1$ & 1863 & 5.03 & 0.106 & 32.25 & 376.82 & 3.10 & 73.3 & 0.50 & 1.90 \\
\hline $\mathrm{S} 2$ & 1830 & 5.27 & 0.095 & 33.60 & 299.79 & 1.74 & 83.6 & 0.35 & 2.14 \\
\hline $\mathrm{S} 3$ & 1800 & 4.88 & 0.117 & 36.27 & 347.83 & 3.16 & 120.7 & 0.46 & 2.07 \\
\hline S4 & 1775 & 4.63 & 0.097 & 40.25 & 247.70 & 2.34 & 84.6 & 0.26 & 1.94 \\
\hline S5 & 1752 & 4.81 & 0.068 & 33.83 & 208.17 & 2.64 & 52.6 & 0.21 & 1.73 \\
\hline S6 & 1745 & 5.12 & 0.078 & 40.25 & 210.81 & 1.78 & 57.8 & 0.24 & 1.35 \\
\hline $\mathrm{S} 7$ & 1715 & 5.08 & 0.093 & 41.48 & 263.51 & 2.86 & 159.12 & 0.28 & 1.94 \\
\hline $\mathrm{S} 8$ & 1685 & 4.66 & 0.076 & 42.07 & 247.70 & 2.45 & 65.0 & 0.26 & 1.99 \\
\hline S9 & 1645 & 5.11 & 0.094 & 43.25 & 260.87 & 2.04 & 142.0 & 0.26 & 1.81 \\
\hline
\end{tabular}
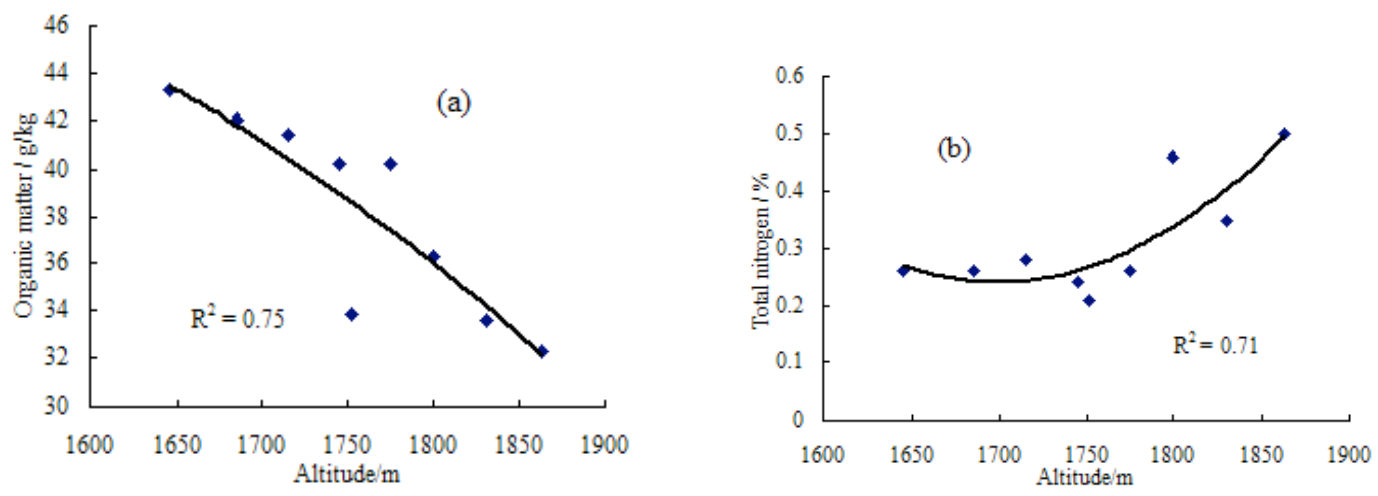

Fig. (2). Variation of soil organic matter (a) and total nitrogen (b) in different altitudes on southern slope.

Table 2. Soil basic properties of northern slope in Funiu Mountain.

\begin{tabular}{|c|c|c|c|c|c|c|c|c|c|}
\hline No. & $\begin{array}{l}\text { Altitude } \\
\text { (m) }\end{array}$ & pH & $\begin{array}{c}\text { Electrical con- } \\
\text { ductivity } \\
(\mathrm{Ms} / \mathrm{cm})\end{array}$ & $\begin{array}{c}\text { Organic } \\
\text { matter }(g / k g)\end{array}$ & $\begin{array}{c}\text { Available ni- } \\
\text { trogen (mg/kg) }\end{array}$ & $\begin{array}{l}\text { Available phos- } \\
\text { phorus (mg/kg) }\end{array}$ & $\begin{array}{c}\text { Available potas- } \\
\text { sium (mg/kg) }\end{array}$ & $\begin{array}{c}\text { Total } \\
\text { nitrogen } \\
(\%)\end{array}$ & $\begin{array}{c}\text { Total } \\
\text { potas- } \\
\text { sium (\%) }\end{array}$ \\
\hline N1 & 1870 & 5.52 & 0.109 & 45.20 & 221.35 & 2.16 & 114.6 & 0.44 & 1.76 \\
\hline $\mathrm{N} 2$ & 1810 & 5.75 & 0.101 & 43.01 & 226.62 & 2.17 & 128.1 & 0.36 & 1.81 \\
\hline N3 & 1782 & 5.17 & 0.077 & 35.22 & 174.57 & 1.81 & 67.2 & 0.41 & 2.02 \\
\hline N4 & 1750 & 5.19 & 0.075 & 32.40 & 208.17 & 1.94 & 74.4 & 0.42 & 2.44 \\
\hline N5 & 1720 & 5.31 & 0.070 & 31.31 & 187.09 & 1.94 & 100.1 & 0.32 & 1.85 \\
\hline N6 & 1674 & 4.86 & 0.090 & 35.82 & 234.52 & 2.56 & 112.5 & 0.36 & 2.00 \\
\hline N7 & 1650 & 4.83 & 0.084 & 45.07 & 255.60 & 3.01 & 83.6 & 0.29 & 2.27 \\
\hline
\end{tabular}

cantly positive with altitude, and the main results of singlevariable analysis through SPSS in Fig. (3). Then there was no other indices correlated with altitude.

\subsection{Comparison between two slopes}

There are certain differences on soil chemical properties between southern and northern slopes from Table $\mathbf{3}$, but the degrees were not the same and the variation trends were difference with the increasing of the plot heights. Soil acidity of sampling plots was stronger on southern slope than on northern slope, but both decreased with altitude on southern or northern slope. Soil electrical conductivity was higher on southern slope, and they were positive correlated with altitude, on northern slope or on southern slope. There 

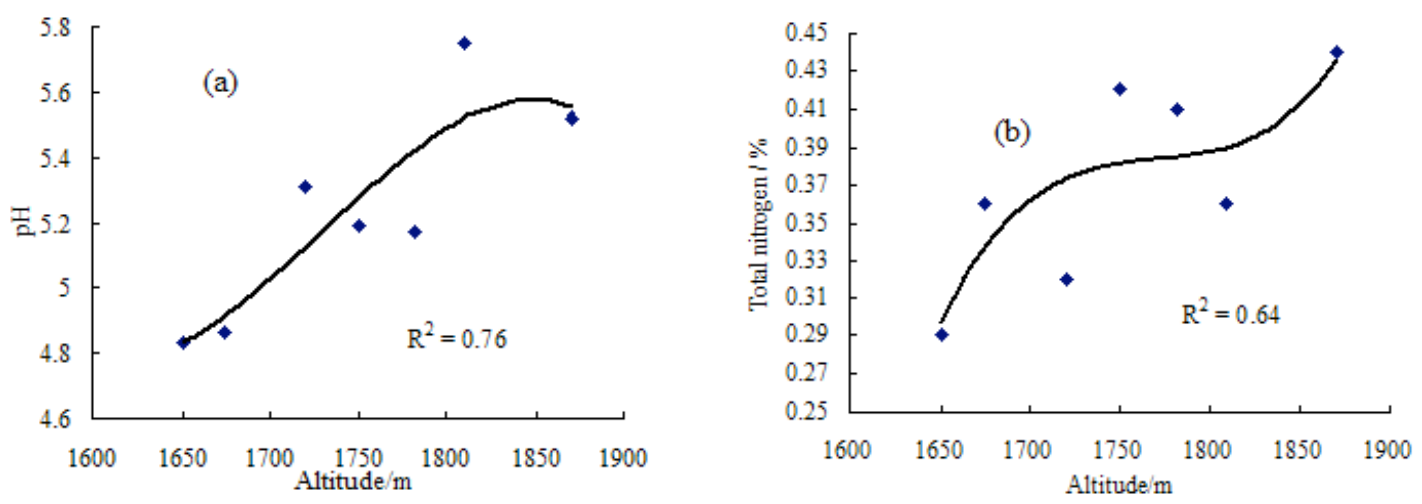

Fig. (3). Variation of soil pH (a) and total nitrogen (b) in different altitude on northern slope.

Table 3. Soil basic properties comparison between southern and northern slopes in Funiu Mountain.

\begin{tabular}{|c|c|c|c|c|c|c|c|c|c|c|}
\hline \multirow{2}{*}{ Basic properties } & \multicolumn{2}{|c|}{ Min. } & \multicolumn{2}{|c|}{ Max. } & \multicolumn{2}{|c|}{ Mean } & \multicolumn{2}{|c|}{ S D } & \multicolumn{2}{|c|}{$\mathrm{C} \mathrm{V} / \%$} \\
\hline & North & South & North & South & North & South & North & South & North & South \\
\hline $\mathrm{pH}$ & 4.83 & 4.63 & 5.75 & 5.27 & 5.23 & 4.95 & 0.332 & 0.221 & 6.35 & 4.46 \\
\hline Electrical conductivity $(\mathrm{Ms} / \mathrm{cm})$ & 0.070 & 0.068 & 0.109 & 0.117 & 0.087 & 0.092 & 0.014 & 0.015 & 16.54 & 16.77 \\
\hline Organic matter $(\mathrm{g} / \mathrm{kg})$ & 25.22 & 32.25 & 45.20 & 43.25 & 38.29 & 38.14 & 7.768 & 4.168 & 21.07 & 10.93 \\
\hline Available nitrogen $(\mathrm{mg} / \mathrm{kg})$ & 174.57 & 208.17 & 255.6 & 376.82 & 215.42 & 273.69 & 27.880 & 57.75 & 12.94 & 21.10 \\
\hline Available phosphorus (mg/kg) & 1.81 & 1.74 & 3.01 & 3.16 & 2.23 & 2.46 & 0.422 & 0.532 & 18.96 & 21.65 \\
\hline Available potassium (mg/kg) & 67.2 & 52.60 & 128.1 & 159.12 & 97.21 & 93.19 & 22.750 & 38.311 & 23.40 & 41.11 \\
\hline Total nitrogen $(\%)$ & 0.29 & 0.21 & 0.44 & 0.50 & 0.37 & 0.31 & 0.055 & 0.102 & 14.78 & 32.59 \\
\hline Total potassium (\%) & 1.76 & 1.35 & 2.44 & 2.14 & 2.02 & 1.87 & 0.252 & 0.232 & 12.45 & 12.39 \\
\hline
\end{tabular}

Note: S D and C V means standard deviation and coefficient of variation, respectively.

is a significant difference of soil organic matter between northern and southern slopes. Namely, it was no striking change with altitude increasing on northern slope while it has obvious decreasing trend on southern slope. Bo be mentioned, there was no change trend of soil available nitrogen with altitude increasing on southern or northern slope. But the value of soil available nitrogen on southern slope was above 27 percent than ones on northern slope, averagely. On southern or northern slope, the soil total nitrogen was positive correlated with altitude, though the value of southern slope was slightly lower than ones on northern slope. Concerning other indices, such as available phosphorus, available potassium and total potassium, there was no significant difference on southern or northern slope, and was no clear correlation with altitude.

\section{DISCUSSION}

As survival carrier of plants, soil was influenced by specific parent material, climate, landform, forming process and humans activity, so its spatial heterogeneity was striking $[20,21]$. Generally, the climate along altitude gradient presented more and more cold or damp within certain elevation, and hydrothermal and vegetation conditions turned to change [22]. Therefore, the spatial pattern and forming process of mountain soil had close relation- ship with altitude. In this article, soil $\mathrm{pH}$, organic matter and total nitrogen were all evidently affected by altitude on northern or southern slope plots from $1640 \mathrm{~m}$ to 1870 $\mathrm{m}$ of Funiu Mountain. This conclusion is similar to the results of Dang et al. on northern slope of Qinling Mountains and Wang et al. on southern slope of Gongga south mountain-Laguigangri Mountain [23, 24]. Concerning the comparison of soil properties between different slope plots, its acidity, conductivity and available nitrogen were significantly higher on southern slope than ones on northern slope, which showed slope had significantly effected on spatial heterogeneity of soil properties. It was both lower temperature and more coniferous trees on northern slope that may aggravate acid leaching process, which cause weak mineralization rate, then lower conductivity and weaker acidity of plots [25]. Because of lower temperature on northern slope, relatively slower rate decomposition of organic matter made significantly lower value of soil available nitrogen on northern slope of Funiu Mountain [26].

This study had showed that soil basic properties of mountain forest had a strong complexity in Funiu Mountain, resulted from many influencing factors, including altitude, slope, temperature, species composition, mineralization rates. Therefore, our expand research should be on the multidimensional positioning monitoring so as to grasp 
spatial variation characteristics of soil basic properties, more scientifically and accurately.

\section{CONCLUSION}

With SPSS 13.0 package, this research has compared the soil basic properties between southern and northern slopes of the Funiu Mountain.Soil pH, organic matter, and total nitrogen presented regularly changed in spatial distribution along with altitude gradient, but the other not. With the ascent of the altitude, soil total nitrogen went up remarkably while both soil acidity and organic matter had a decreasing trend, on northern or southern slope. Compared with soil properties of plots on northern slope, soil acidity, electrical conductivity, and available nitrogen were higher on southern slope, but the other no great difference or similarly. It is both altitude and slope direction that are the important factors influenced spatial differentiation of soil basic properties in Funiu Mountain.

\section{CONFLICT OF INTEREST}

The author confirms that this article content has no conflict of interest.

\section{ACKNOWLEDGEMENT}

The authors thank the Institute of Plant Protection and Soil Fertilizer, Hubei Academy of Agriculture Science of China, for assistance in soil properties determinations. This research is supported by the National Natural Science Foundation of China (No. 41371105).

\section{REFERENCES}

[1] F. Xiao, Y. Du, F. Ling, S. J. Wu, and Y. Yan, "Analysis of relation between change of lakes and the spatial pattern of soils in the lake district in Sihu drainage basin, middle reaches of Yangtze River", Wetland Science, vol. 10, pp. 8-14, 2012.

[2] Z. C. Chen, C. Y. Hao, C. H. Liu, and X. D. Ding, "Influences of barrier function on the temporal and spatial characteristics of temperature, precipitation, land cover and primary productivity in Mt. Funiu", Ecology and Environmental Sciences, vol. 22, pp. 761-766, 2013.

[3] S. S. Parker and J. P. Schimel, "Soil nitrogen availability and transformations differ between the summer and the growing season in California grassland", Applied Soil Ecology, vol. 48, pp. 185-192, 2011.

[4] C. B. Craft and C. Chiang, "Forms and amounts of soil nitrogen and phosphorus across a longleaf pine-depressional wetland landscape", Soil Science Society of America Journal, vol. 66, pp. 1713-1721, 2002.

[5] N. Monokrousos, E. M. Papatheodorou, J. D. Diamantopoulos, and G. P. Stamou, "Temporal and spatial variability of soil chemical and biological variables in a Mediterranean shrubland", Forest Ecology and Management, vol. 202, pp. 83-91, 2004.

[6] Z. L. Liu, "Should sustainable consumption and production be a policy priority for developing countries", Natural Resources Forum, vol. 34, no. 1, pp. 85-89, 2010.

[7] S. F. Wang, X. K. Wang, and Z. Y. Ouyang, "Effects of land use, climate, topography and soil properties on regional soil organic carbon and total nitrogen in the Upstream Watershed of Miyun
Reservoir, North China", Journal of Environmental Sciences, vol. 24, pp. 387-395, 2012.

[8] C. H. Xiang, J. W. Luan, Z. S. Luo, and Y. B. Gong, "Labile soil organic carbon distribution on influenced by vegetation types along an elevation gradient in west Sichuan, China”, Acta Ecological Sinica, vol. 30, pp. 1025-1034, 2010.

[9] Q. M. Zhang, D. X. Wang, M. G. Gong, and L. N. Zhang, "Changes in physicochemical properties of forest soil along different altitudes in Huoditang of Qinling Mountains", Journal of Soil and Water Conservation, vol. 25, pp. 69-73, 2011.

[10] X. R. Wang, and Z. X. Che, "The spatial variation analysis on physical and chemical indicators of Picea Crassifolia in Qilian Mountains", Journal of Gansu Forestry Science and Technology, vol. 37, pp. 6-12, 2012.

[11] Q. H. Tian, Y. Liu, Q. F. Cai, G. Bao, W. P. Wang, W. L. Xue, H. M. Song, and Y. Lei, "The maximum temperature of MayJuly inferred from tree-ring in Funiu Mountain since 1874 AD", Acta Geographica Sinica, vol. 64, pp. 879-887, 2009.

[12] X. L. Lu, N. Hu, S. Y. Ding, Y. L. Fan, B. H. Liao, Y. J. Zhai, and J. Liu, "The pattern of plant species diversity of Funiu Mountain Nature Reserve", Acta Ecological Sinica, vol. 30, pp. 57905798, 2010.

[13] R. Li, G. F. Jiang, and B. C. Liao, "A study on the spatial cluster and layout of tourism industry of mountain scenic resort", Journal of Northwest University, vol. 38, pp. 1011-1014, 2008.

[14] J. J. Ma, "Laws of soil vertical variations on southern slope of Mt. Funiu: simultaneous study on north boundary of subtropical zone", Acta Geographica Sinica, vol. 59, pp. 998-1011, 2004.

[15] X. L. Zhu and Z. C. Yao, "Distributing structure of biodiversity of edible mountain wild herbs along altitude gradient in Baotianman Nature Reserve", Journal of Henan University of Science and Technology (Natural Sciences Edition), vol. 30, pp. 6569, 2009.

[16] C. Y. Tian, X. L. Hu, X. J. Zheng, and G. J. Kong, "A preliminary study on the vertical distribution of broad-leaved evergreen plants in Funiu Mountain in Henan", Journal of Henan Agriculture University, vol. 44, pp. 690-694, 2010.

[17] R. K. Schofield and A. W. Taylor, "The measurement of soil Ph. Soil Science Social American Processing”, vol. 19, pp. 164-167, 1955.

[18] A. Walkley and I. A. Black, "An examination of the Degtjareff method for determining soil organic matter, and a proposed modification of the chromic acid titration method", Soil Science, vol. 37, pp. 29-38, 1934.

[19] F. M. Hons, L. A. Larson-Vollmer, and M. A. Locke, "NH4OAcEDTA extractable phosphorus as a soil test procedure", Soil Science, vol. 149, pp. 249-256, 1990.

[20] H. M. Chen, Environmental Pedology, Beijing: Science Press, 2010.

[21] S. K. Behera and A. K. Shukla, "Total and extractable manganese and iron cultivated acid soils of India: Status, distribution and relationship with some soil properties", Pedosphere, vol. 24, pp. 196-208, 2014.

[22] V. O. Biederbeck, D. Curtin, O. T. Bouman, C. A. Campbell, and H. Ukrainetz, "Soil microbial and biochemical properties after ten years of fertilization with urea and anhydrous ammonia", $\mathrm{Ca}$ nadian Journal of Soil Science, vol. 76, pp. 7-14, 1996.

[23] K. L. Dang, C. L. Zhang, H. B. Chen, F. L. Han, and Q. Z. Yu, "Spatial distribution and variation pattern of soil fertility at different altitude on south slope in Qinling Mountains", Scientia Silvae Sinicae, vol. 42, pp. 16-21, 2006.

[24] J. L. Wang, Y. H. Ou, Z. H. Wang, T. J. Chang, P. Li, Z. X. Shen, and Z. M. Zhong, "Influential factors and distribution characteristics of topsoil organic carbon of alpine grassland ecosystem in the south slope of Gongga south mountain-Laguigangri Mountain", Chinese Journal of Soil Science, vol. 41, pp. 346350,2010 
[25] B. N. Noller, N. A. Currey, G. P. Ayers, and R. W. Gillett, "Chemical composition and acidity of rainfall in the Alligator River Region, Northern Territory, Australia", Science of the Total Environmental, vol. 91, pp. 23-48, 1990.
[26] M. D. Corre, R. R. Schnabel, and W. L. Stout, "Spatial and seasonal variation of gross nitrogen transformations and microbial biomass in a Northeastern US grassland", Soil Biology \& Biochemistry, vol. 34, pp. 445-457, 2002.

Received: September 18, 2014

Revised: December 22, 2014

Accepted: December 31, 2014

(c) Zhang et al.; Licensee Bentham Open.

This is an open access article licensed under the terms of the Creative Commons Attribution Non-Commercial License (http://creativecommons.org/licenses/by$\mathrm{nc} / 3.0 /$ ) which permits unrestricted, non-commercial use, distribution and reproduction in any medium, provided the work is properly cited. 